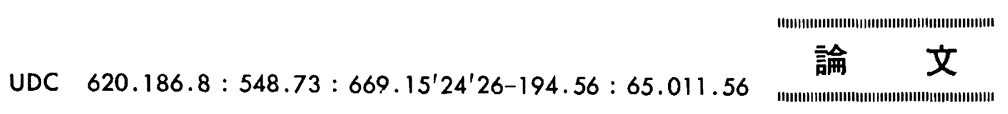

\title{
$\mathrm{X}$ 線回折による結晶粒度自動測定技術の開発*
}

\author{
星野 和夫 ${ }^{* *}$ 。伊東建次郎 ${ }^{* *}$. 藤岡外喜夫** \\ 円山 弘 ${ }^{* * *} \cdot$ 荒木 宏侑 ${ }^{* * *} \cdot$ 熊沢 昭二***
}

\section{Measurement of the Grain Size by X-ray Diffraction}

\author{
Kazuo Hoshino, Kenjiro Ito, Tokio Fujoka, Hiromu Maruyama, \\ Hiroyuki Araki, and Shoji Kumazawa
}

\begin{abstract}
Synopsis:
We have developed the technique by which the grain size of austenitic stainless steels can be measured nondestructively and rapidly by utilizing the fact that the numbers of spots along Debye Scherrer rings relate to the numbers of grains in the area irradiated by $\mathrm{X}$-ray.

The principle and results of this study are as follows.

1) It is shown theoretically that the numbers of spots along Debye Scherrrer rings diffracted by $\mathrm{X}$-ray relate to those of grains in the irradiated area. Thus the diameter of grains, $d$ can be counted in principle but this can not be done by a simple method. The relative standard deviation $(D)$ of $\mathrm{X}$-ray intensities which are measured at the points distributed along Debye Scherrer rings is theoretically shown to be related to the diameter of grains and its reliability is proved experimentally.

2) The precision of proportional relation between $D$ and $d$ depends on sampling numbers. Larger sampling numbers give the higher precision. The number of points for intensity measurement along Debye Scherrer rings is limited by the limitation of the space, and consequently the number is enlarged by changing the measuring positions.

3) The value of $D$ are affected by the prefferred orientation and mixture of large grains. These effects should be corrected in order to enhance the precision and this can be done mathematically.
\end{abstract}

\section{1. 緒言}

金属材料の結晶粒の大きさが材料特性の利害得失に及 ぼす影響は使用環境や用途によつて異なる．結晶稙が粗 いと靶性を損权たり，塑性変形を受けたときオレンジピ ールと称する肌あれが発生したりする，一方，結晶粒が 細かいと常温での強度は上昇するが高温での強度は低下 する.また常温では充分な延性が 得られない場合もあ る.

オーステナイト $(r)$ 系ステンレス鋼においても例外 ではなく，実用途に供されるときはその用途に応じて結 晶粒をコントロールした材料が供給されている.

しかし， 系ステンレス鋼は，SUS321 のような Cr カーバイドの析出に対しての安定化鋼や極低炭素以外は $600 \sim 900^{\circ} \mathrm{C}$ の範囲で鋭敏化する1)ことおよび再結晶温
度が高い2)ことなどから一般に $1000 \sim 1100^{\circ} \mathrm{C}$ で燒鈍 されるので, 結唱粒が粗大化しやすい条件下にある. し たがつて，燒鈍に際しては温度と通板速度のきびしい管 理が必要とされ充分なる注意が払われている.

しかし，実際に焼鈍ラインを通板された材料の結晶粒 の大きさが判明するには，かなりの時間的遅れを余儀な くされている.なぜならば, 現在実施されている結晶粒 度の測定方法は, 被測定物である材料を機械的か化学的 に鏡面研摩しその後適当な液で化学腐食し結晶粒界を観 察することによつて実施されている。このような過程を へて検出された組織をもとにして結晶粒の大きさを導き だす方法としてはJIS G0551，G0552 に比較法と切断 法が規定されている．前者は簡便であるが一種の官能試 験であるために個人誤差が生じやすい，後者は誤差は少 ないが, 結晶粒界の数を読みとるのにかなりの労力と時

* 昭和 52 年 4 月本会講演大会にて発表 昭和 52 年 6 月 15 日受付 (Received June 15, 1977)

** 日新新鋼(株) 周南製鋼所 (Shunan Works, Nisshin Steel Co., Ltd., 4976 Tonda Shin-nanyo-City 746)

*** 理学電機 (株) (Rigaku Corporation) 
間を要する．最近では結晶粒界の数の測定を光学系壱近 じて得られる情報をもとに読みとり自動的に結晶粒度を 算出する装置が市販されている.

しかし，この装置はあくまでも組織が榆出されたあと での情報処理装置であり，鋼带および鋼板の製造工程中 に迅速に結晶粒度を求めるまでには至つていない，そこ で筆者らは，焼鈍酸洗ラインで非破壊的でかつ迅速に結 晶粒度を測定する装置および技術の開発をすすめてき測 定可能な段階に至つたので，その原理および結果につい て報告する。

\section{2. 測 定 原 理}

\section{$2 \cdot 1$ 基本的測定原理}

結晶方位がランダムでかつ微細な結晶粒をもつ材料の X線回折像は，一般に連続に近いデバイリングを与え， 同一X線光学系のもとで大きな結晶粒をもつ材料の X 線 回折像は斑点状のデバイリングを与えることはよく知ら れている.このことから，デバイリングの斑点の状態を 定量的に観察することにより，結晶粒径が定量的に測定 されることが容易に推察される。

Photo. 1 に結晶粒径の異なる二つの試料によるデバ イリングを示した．同一X線光学系のもとでは，結唱粒. 径が小さいときデバイリングの中の玟点の数が多く, 径 が大きいときはその逆にデバイリングの斑点の数は少な くなる.したがつて，デバイリングの中の斑点の数を数
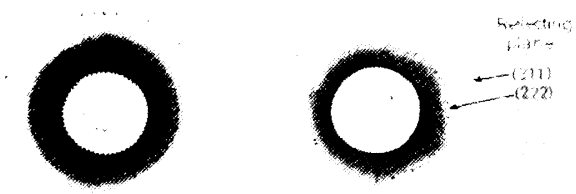

jost jiz 120u jrain bize $3 \%$ a

Photo. 1. Debye Scherrer patterns of stainless steel of different grain size.

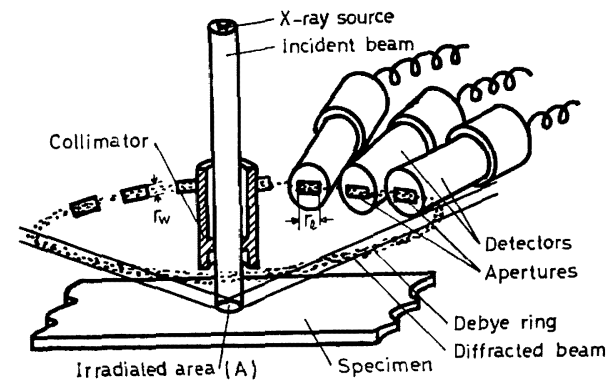

Fig. 1. Schematic diagram of the measuring principle.

えることにより結晶粒径が測定される・しかし，この方 法は迅速測定という面では目的を達成しない，

Fig. 1 に本研究で用いる迅速でかつ非破壊的な結晶粒 度測定法の原理図を示した。いま，X線に照射された試 料の面積を $A$ ，そこに存在する結晶粒の径をdとし， $\mathrm{X}$ 線の侵入深さを $x$ と寸れば，X線に照射された領域 $(\mathrm{A})$ 内に存在する結晶粒の数の平均值 $\left.\bar{N}_{i r}\right)$ は近似的に(1),

(2) 式で与えられる.

$$
\begin{array}{ll}
\bar{N}_{i r} & =A x / d^{3} \quad(x \gg d) \\
N_{i r} & =A / d^{2} \quad(x \ll d)
\end{array}
$$

$\mathrm{X}$ 線の侵入深さ $x$ は回折に寄与する有効厚さを示し， Fig. 1 のように X 線が垂直入射する場合（3）式とな $ろ^{3)}$.

$$
\begin{aligned}
& x=K x \cdot \sin \dot{\varphi} / \mu(1+\sin \phi) \quad \ldots \ldots \ldots \ldots \ldots \ldots . . \\
& \text { ただし, } K x=\ln \{1 /(1-G x)\}, \quad \phi=2 \theta-90^{\circ}
\end{aligned}
$$

ここで， $\mu$ は線吸収係数であり， $G x$ は瞧限㕌さの試料 に対して何パーセントまでの回折強度を有効厚さとする かを示す値である. Table 1 に $G x$ を 90，95，99\%に したときの $\mathrm{CoK}_{\alpha}, \mathrm{CrK}_{\alpha}$ による $\gamma$ 系ステンレス鋼の有 効厚さを示した。

$\mathrm{X}$ 線に照射された領域 $\mathrm{A}$ 内の結晶粒のうち，回折条件 を满す結晶粒の数の平均值 $\left(\bar{N}_{d g}\right)$ は $(4)$ 式で与党られ $3^{4)}$.

$$
\bar{N}_{d g}=\bar{N}_{i r} \cdot P / 2 \cdot \cos \theta(\phi+\eta)
$$

\begin{tabular}{|c|c|c|c|c|c|c|}
\hline \multirow{2}{*}{$\mathrm{X}$-ray } & \multirow{2}{*}{$\begin{array}{l}\text { Reflecting plane } \\
\text { (hkl) }\end{array}$} & \multirow{2}{*}{$\begin{array}{c}\text { Diffraction angle } \\
2 \theta\left({ }^{\circ}\right)\end{array}$} & \multirow{2}{*}{$\begin{array}{c}\text { Linear absorption } \\
\text { coefficient } \\
\left(\mathrm{cm}^{-1}\right)\end{array}$} & \multicolumn{3}{|c|}{ Depth of X-ray penetration $(\mu)$} \\
\hline & & & & $90 \% *$ & $95 \% *$ & $99 \% *$ \\
\hline $\mathrm{CoK}_{\alpha}$ & 311 & 111.5 & 895 & 6.9 & 9.0 & 13.8 \\
\hline $\mathrm{CrK}_{\alpha}$ & 220 & 128.7 & 836 & 10.6 & 13.8 & 21.2 \\
\hline
\end{tabular}

ここで，Pは多重度因子， $\theta$ は Bragg 角， $\phi$ は試料か

Table 1. Effective penetration depth according to measuring Iconditions.

*: The diffracted $\mathrm{X}$-rays intensity ratio to the one of the sample having infinite thickness. 
らX線源をみた立体伯，そしては 回折線の自然幅と試 料のひずみによる因子である.

いま，X線源として $\mathrm{CoK}_{\alpha}$ を用い半均して $14 \mu$ 以上 の結晶粒径をもつ $\gamma$ 系ステンレス鋼の（311）反射を観 測した場合，近似的には試料の表面層にある結晶粒によ る回折斑点のみが観測されていることになる、したがつ て，(2)，(4) 式を用いて計算される回折斑点の数がデ バイリング上に現われることになる。

デバイリングの 円周に沿つて長さ $r_{c} ，$ その直觕方向 に回折線の半価幅より十分大きな幅 $r_{w}$ をもつアパーチ †を置いたとき，アパーチャの中に入る斑点の平均的な 数 $\left(\bar{N}_{g}\right)$ はデバイリング全周の長さを $L_{D}$ とした場合, (5) 式となる.

$$
\bar{N}_{g}=\bar{N}_{d g} \cdot r_{e} / L D
$$

また (2)，(4)，および (5) 式から $N_{g}$ と結晶粒径と の問に，(6) 式の関倸が成り立つ.

$$
\bar{N}_{g}=K^{2} \cdot A \cdot r_{e} / d^{2}, \text { または } d=K \sqrt{A r e} \cdot 1 / \sqrt{\bar{N}_{g}}
$$

$$
\text { ただし， } K=\sqrt{P / 2 \cdot L_{D} \cdot \cos \theta(\phi+\eta)}
$$

一方，Fig. 1 に示したようにデバイリングの内周に沿 つて同一サイズの $n$ 個のアパーチャを並べ，それでれの アバーチャ内に入る斑点の数を $N_{g 1}, N_{g 2} \cdots \cdots N_{g i} \cdots \cdots N_{g n}$ とすると， $N_{g i}$ は結晶粒がランダム方位である仅定か ら回折斑点の分布もランダムであり Poisson 分布に従 う5). したがつて， $n$ 個のアパーチャによる斑点の数の 相対標準偏差 $\left(D_{g}\right)$ は $(7)$ 式となる.

$$
D_{g}=1 / \bar{N}_{g} \cdot \sqrt{\sum_{i=1}^{n} \overline{(n g}\left(N_{g i}-\bar{N}_{g}\right)^{2} / n}=1 / V \overline{\bar{N}}_{g} \ldots
$$

(7) 式における $N_{g i} ， \bar{N}_{g}$ は簡単に実測しえないが， それそれれのアパーチャを通過する斑点によるX線強度の 計数值 $N_{s i}$ は容易に実測できる.この $N_{s i}$ は $N_{g i}$ に比 例することからX線の発生機構からくる統計变動を無視 して考えると $N_{s i}$ の相対標準偏差 $(D)$ は $D_{g}$ に等しく なり，(8) 式で表わされる.

$$
D_{g}=D=1 / \bar{N}_{s} \cdot \sqrt{\sum_{i=1}^{n}\left(N_{s i}-\bar{N}_{s}\right)^{2} / n} \ldots
$$

また，(6)，(7)，(8) 式から（9）式が得られる.

$$
d=K \cdot \sqrt{A \cdot r_{c}} \cdot D \cdot
$$

（9）式は回折斑点の粒状性からくるX線強度の相対標 準偏差を求めることにより, 結唱粒径を求めうることを 意味している.

\section{2 原理の適用と誤差について}

前述の原理は次のような仮定の上に成り立つている.

(a) 1 つの試料内では絬晶粒径は等しく, 回折に寄与する 結晶粒は試料表面に存在するもののみであり，かつそれ
らの結晶粒による回折玟点は等しい回折強度を与克る。 (b) 試料は集合組織をもたないすなおちデバイリン グの円凬にそつて回折斑点はランダムに分布している.

しかし，実用材料はこれらの仮定を完全には满足しえ ない，実際面においてこの測定原理が実用材料にどれく らい適用できるか，また適用するにはどのような対策を とるべきかについて検討をくわえる。

この検討に用いたX線光学系を Fig. 2 亿示す. $N_{s i}$ の 測定はデバイリングの円周に沿つて $n$ 個のアパーチャを 置くかわりに 1 個のアパーチャを用い，試料を試料面内 で約 $15^{\circ}$ づつ回転させることにより行ない，その測定回 数を 24 とした。供試材として Table 2 に示した結晶 粒径をもつSUS 304 を用いた。

$2 \cdot 2 \cdot 1$ X線照射野（コリメータサイズ）とアパーチ ヤサイズが検量線におよぼす影響

（9）式の妥当性および比例定数Kを検討するためにコ リメータサイズとアパーチャサイズの組合せを変えて実 駼を試みた，Fig. 3 は 0.3, 1.0, $1.4 \mathrm{~mm} \phi$ のコリメー 夕にそれぞれ $20,8.9,5.7 \mathrm{~mm}$ のアパーチャ $\left(r_{e}\right)$ を 組合せたときの実験結果を示す， $D_{m}$ はバックグラウン ドを含えだ計数値の相対標準编差であり，dは切断法に より求めた結晶粒径である。この実験結果から次のこと がいえる。

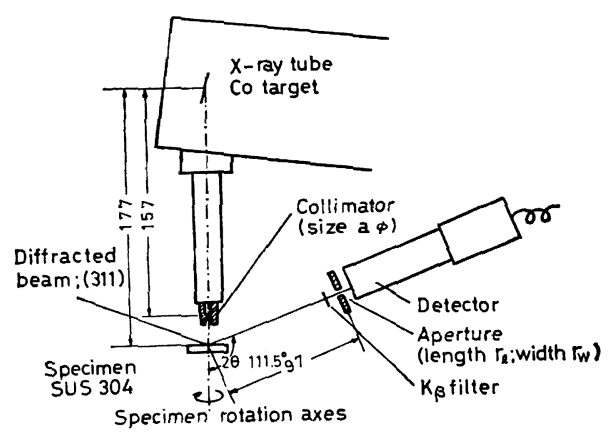

Fig. 2. X-ray optics employed for the experiment.

Table 2. Specimen No., grain size No. and grain size of the specimens used for measurement.

\begin{tabular}{c|c|c}
\hline Specimen & Grain size No. & Grain size $(\mu)$ \\
\hline 1 & 11.2 & 8.4 \\
2 & 9.7 & 13.8 \\
3 & 9.0 & 17.5 \\
4 & 7.8 & 26.4 \\
5 & 6.9 & 37.0 \\
6 & 5.2 & 66 \\
7 & 4.4 & 87 \\
\hline
\end{tabular}




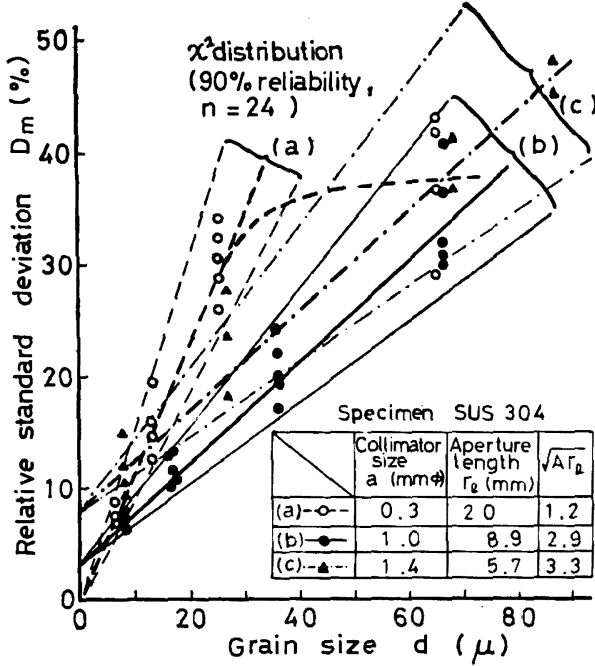

Fig. 3. Difference of the calibration curve due to difference in combination of the aperture length with the collimator size.

(1) $d$ と $D_{m}$ との検量線の勾配は，(9) 式の $\sqrt{A r_{e}}$ の值によつて異なるが，完全な正比例関係を示さない。 したがって， $D_{m}$ の $d$ 依存性は実験值で求好る必要があ る.

(2) $D_{m}$ とdの正比例関係は検量線の全領域になく, $d$ のある限られた範囲内に存在する.この比例関係の成 り立つ範囲は検量線の勾配が低いほど長い。この現象は コリメータサイズと $r_{e}$ の值の組合せに依存していると 考えられる．この現象をさらに明確にするために，コリ メータサイズ $0.8,1.2 \mathrm{~mm} \phi$, アパーチャ長さ $\left(r_{e}\right) 2.7$ $\mathrm{mm}$ 組み合せについて実験し，検量線が直線領域からは ずれる限界の結晶粒径（ $d_{\max }$. $)$ について検討した。 そ の結果を Fig. 4 に示しだ.縦軸は検量線が直線域から はずれる限界の結晶粒径であり，横帆は使用したコリメ ータサイズである.Fig.4 より，アパーチャの長さ，コ リメータサイズが小さいと直線領域が狭く, アパーチャ の長さ,コリメータサイズが大きくなるとその直線領域 が広くなることがわかる，この原因として，一つのアパ 一チャが何個以上の斑点をとらえているかによると考え られる. 同一光学系のもとで回折斑点をフィルムに撮影 し検討した絬果，一つのアパーチャ内に最低 3〜4 個の 回折斑点が通過すれば検量線は直線領域を保持しうるこ とがわかつた。

(3) $d$ と $D_{m}$ との比例定数が 小さくなるにしたがつ て，検量線は零点を通らなくなると同時に，この切片 の值が大きくなる，切片の值が大きな場合，小さな結晶

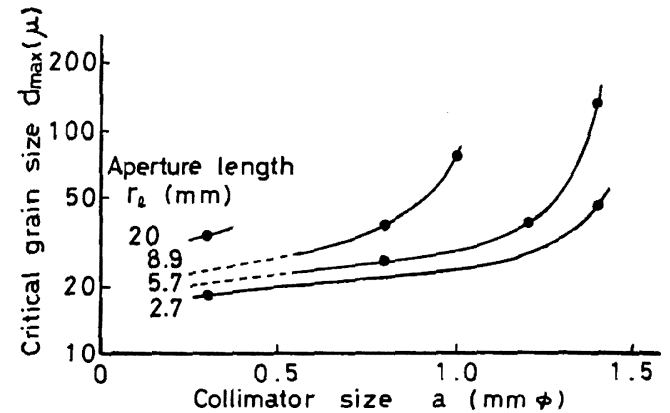

Fig. 4. The relations between the critical grain size $\left(d_{\max }\right)$ with which the calibration curve deviates from the linear region, and the collimator size and the aperture length.

粒径において $D_{m}$ のバラツキ幅が大きくなる。これは測 定原理の項で 鷁視したX $\mathrm{X}$ 線の発生機構からくる統計変 動，バックグラウンドの統計変動抢よび集合組織からく る影響などに起因すると考えられ，次項にてこれらの因 子がどのように影響しているかについて検討する。

$2 \cdot 2 \cdot 2$ バックグラウンド, 回折強度および 集合組織 による影響

バックグラウンドの計数值 $\left(N_{b}\right)$ に対する相対標準偏 差 $\left(D_{b}\right)$ と回折線の平均計数值 $\left(\bar{N}_{s}\right)$ からくる相対標準 偏差 $\left(D_{x}\right)$ は $D$ の測定に必ず附随してくる. また，材 料に集合組織がある場合, 集合組織により回折線の計数 值にバラツキが生ずる。この集合組織による相対標準偏 差 $\left(D_{t}\right)$ も考虑する必要がある. $D, D_{b}, D_{x}$ および $D_{t}$ は互に独立であるから，実測される相対標準偏差 $\left(D_{T}\right)$ は（10）式で与えられる.

$$
D_{T}=\sqrt{D^{2}+D_{b}^{2}+D_{x}^{2}+D_{t}^{2}}
$$

使用するX線光学系と測定条件がきまると, $\bar{N}_{s}, N_{b}$ の 值は測定試料の粒径の差異にもとづく变化にはほとんど 関係なくきまつてくる。したがつて， $D_{b}, D_{x}$ 洁試料間の 粒径に関係なく一定の值とみなせる。亦た，集合組織も 試料間の粒径に関係なく一定の集積度を示すとすると， $D_{t}$ も一定の值になる.


の值を示すとき $D$ に対し $D_{T}$ がどのような影響を及湆す かを示したものである： $D_{1}$ の值は $D$ が大きいときには $D_{T}$ に大きな影響を与えないが $D$ が小さいとき $D_{T}$ に大 きな影響を及ぼすことになる。

この計算值にもとづいて Fig. 3 の実験結果を考察する と（a）は見掛け上零点を通る検量線になつているが， 実際江零点近浐で検量線は直線でなく曲線になり, 零点 


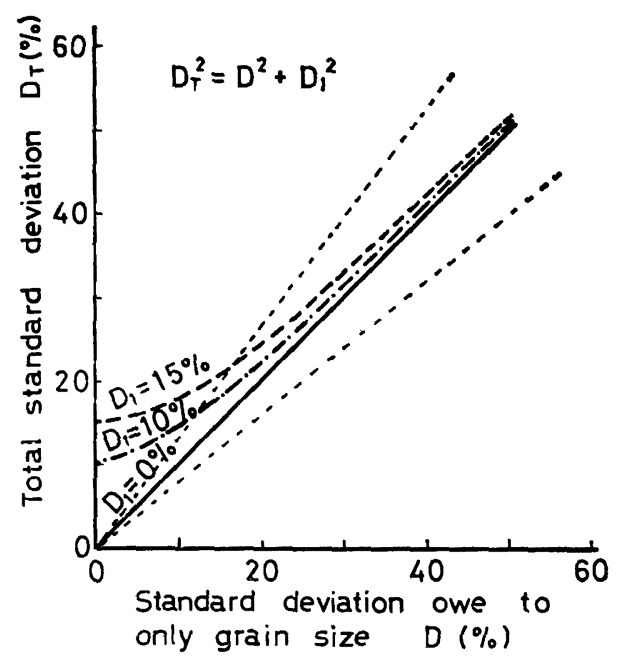

Fig. 5 Estimation of effects on the total standard deviation $\left(D_{T}\right)$ by the standard deviations $\left(D_{1}\right)$ other than that due to the grain size.

を通らないものと思われる。（b)，(c) は小さな絬晶粒 径において $D$ より $D_{1}$ が大きな値になり，零点を通らな い検量線になつている、また，(c) は（b) より $D_{1} の$ 影響が大きく作用して $D_{m}$ のバラツキとして現われたも のと推察される.

\section{$2 \cdot 2 \cdot 3$ サンプリング数による誤差}

相対標準偏差の精度は（8）式にみられるようにnの 大きさ，すなわち個々の計数值のサンプル数をいくらに するかによつて大きく支配される。サンプリング数に依 存する $D$ の誤差は $\chi^{2}$ 分布から評洒できる. サンプリン グ数に対する $\chi^{2}$ 分布から求めた標準偏差推定值の誤差 を Fig. 6 に示した。

サンプリング数を增していくと急激に誤差が少なくな つてくる.したがつて高い精度を要求主る測定ではサン プリング数を多くすることが不可久の要素である.

\section{3．装置，供試材および実験方法}

\section{1 装 置}

結晶粒度測定装置として試作した装置のブロックダイ ヤグラムを Fig. 7 に示した. 大別して，X線発生装置 部, 測定へッド部, 計数演算处理部, 架台部の 4 要素か ら構成されている.

$\mathrm{X}$ 線発生装置はX線管電圧波形がコンスタントポテン シャルタイプの $2 \mathrm{~kW}$ 型を用いた。

測定ヘッド部はX線源，コリメータ，アパーチャおよ び計数管からなつており，これらがすべてへッド部のベ

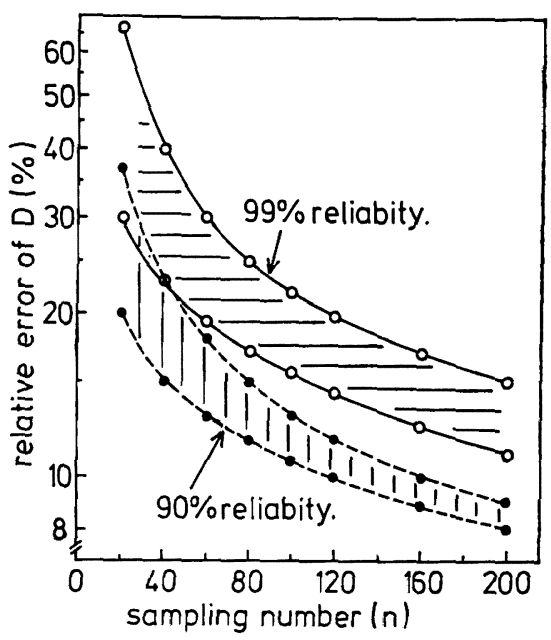

Fig. 6. The relation between the sampling number and reliability of standard deviation calculated from $\chi^{2}$ distribution.

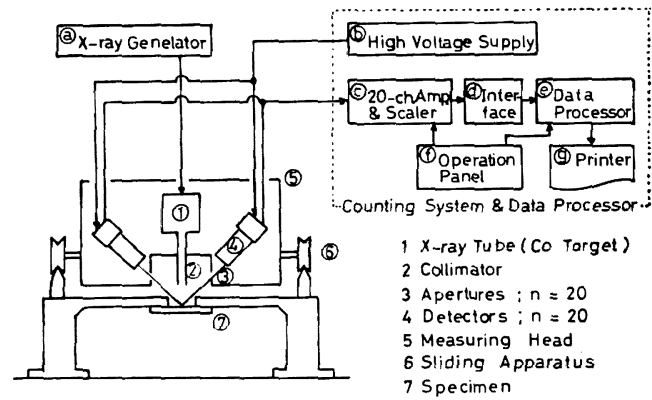

Fig. 7. Block diagram of the measuring system of the grain size of stainless steel.

一スの上に組み付けられた一体構造になつている、X線 光学系は完全な固定光学系であり,コリメータの径およ びアパーチャの長さは，前項の検討にもとづきそれぞれ $0.8 \mathrm{~mm} \phi, 9.4 \mathrm{~mm}$ （デバイリングに沿つて $6^{\circ}$ ） とし た．アパーチャの位置は，X線管球に Co 対陰極を用 い, $\gamma$ 采ステンレス鋼の (311) による $\mathrm{K}_{\alpha}$ 回折線のみ を受光する角度位置に固定した・アパーチャの幅は試料 の合金成分の固溶量の変動にもとづいて生ずる回折角の 変化および試料位置に若干の変化があつても回折線の積 分幅が全部受光できるように配虑し， $2.6 \mathrm{~mm}$ とした. アパーチャの数は（8）式の nに相当し，精度を高める ためには多いことが好ましいが寸法上の制約から 20 個 とした。

$n=20$ では精度が腎い，この欠点を補うためには測定 箇所を增してサンプリング数を大きくする方法を採用す 
Table 3. Fabrication history of measuring specimens and groups seperated by total percentage of cold rolled reduction. The figure in bracket shows number of specimens.

\begin{tabular}{|c|c|c|c|c|c|}
\hline Moulding & Hot rolling & $\begin{array}{c}\text { Times of intermediate } \\
\text { annealing }\end{array}$ & \multicolumn{2}{|c|}{$\begin{array}{l}\text { Total percentage of cold } \\
\text { rolled reduction }\end{array}$} & Groups \\
\hline $\begin{array}{c}\text { Ingot } \\
{[7]}\end{array}$ & $\begin{array}{l}\text { Steckel mill } \\
{[18]}\end{array}$ & $\begin{array}{l}\text { None } \\
{[55]}\end{array}$ & $\begin{array}{l}\leq 55 \% \\
55 \sim 65 \% \\
\geq 65 \%\end{array}$ & $\begin{array}{l}{[12]} \\
{[21]} \\
{[22]}\end{array}$ & $\begin{array}{l}\text { I } \\
\text { II } \\
\text { III }\end{array}$ \\
\hline $\begin{array}{c}\text { Continuous casting } \\
{[110]}\end{array}$ & $\begin{array}{l}\text { Tandem mill } \\
{[99]}\end{array}$ & $\begin{array}{c}\text { Once or twice annealing } \\
{[62]}\end{array}$ & $\begin{array}{l}\leq 64 \% \\
64 \sim 74 \% \\
74 \sim 84 \% \\
\geq 84 \%\end{array}$ & $\begin{array}{l}{[8]} \\
{[17]} \\
{[32]} \\
{[5]}\end{array}$ & $\begin{array}{l}\text { IV } \\
\text { V } \\
\text { V } \\
\text { VII }\end{array}$ \\
\hline
\end{tabular}

る、架台車はこの目的のために設けたもので，测定試料 に対し一定の距朔を保持しながら水平移動できる機構に なつており，多くの位置での測定を可能ならしめてい る*.

計数管はアルゴンを封じた比例計数管であり，20 個 のアパーチャに対応して 20 個配置してある.

計数演算処理部は 20 個の計数管がそれぞれ独立に検 出したX線強度をマルチチャンネルスケーラでそれぞれ 独立に計数し，インタフェースを介して順次読灭出し， あらかじめ指定したプログラムにしたがつて演筧処理を 実行し，結果をプリントアウトする.

演算の内容は測定モードにより以下に示すことが可能 になるシステムになつている.

（1）計数管補正モード

比例計数管は計数管密（マイカ）厚，訃数管ガス非 若干の相違があることが多く，必ずしも20 個の計数管 が同じ計数効率を示さないままた，長時間使用すること による劣化の度合も等しいとは限らないしたがつて， それぞれの計数管について計数効率の補正を定期的に行 なつておく必要がある.

この補正は後述する標準試料を用いて各計数管の補正 係数を求め,コンピュータに記隐させ,精度測定時にそれ ぞれの計数管個有の補正係数を測定值に乘じて行なう。

(2) 測定モード

粒径測定を実行するモードであり基本的には（11）， (12)，(13）式にしたがつた演算を行なう。

$$
\begin{aligned}
& D_{m}=\sqrt{\frac{\sum_{i=1}^{n_{c}}\left(\frac{I_{i}}{C_{i}}-\bar{I}\right)^{2}}{n_{c}-1}} \times \frac{100}{I} \\
& d=\frac{D_{m}-B_{j}}{A_{j}} \ldots \ldots \ldots \ldots \ldots \ldots \ldots \ldots \ldots \ldots \ldots \ldots \ldots \\
& \text { G.S. N }=17.283-2.885 \ln d
\end{aligned}
$$

ただし， $I_{i}: i$ 番目の計数管による計数值

$$
\begin{aligned}
& \bar{I}: n_{c} \text { 個の計数管による平均計数値 } \\
& C_{i}: i \text { 番目の計数管の補正係数 } \\
& n_{c}: \text { 計数管の数 } \\
& A_{j}: \text { 検量線の勾配 }(j: \text { 検量線の種類 }) \\
& B_{j}: \text { 検量線の切片の値 } \\
& \text { G. S. N. : JIS 規格で示される粒度番号 }
\end{aligned}
$$

(3) 計数值直接読取りモード

訃数系を梌査するためのモードであり，任意の計数管 から計数值を直接読み取ることができる.

\section{2 供試材および実験方法}

周南製銅所の No. 4 連続燒鈍酸洗 ライン6) 通板さ れた SUS304 のうちで，特に結晶粒度の管理を必要と している板厚 $2.0 \mathrm{~mm}$ 以下のコイルから無作為に抽出 した117 コイルのカット・サンプルを測定対象とした. これらのコイルの製造履歴の概要を Table 3 に示す.

標準試料は鋭敏化 $\left(650^{\circ} \mathrm{C}\right.$ で $1 \mathrm{~h}$ 保持) した SUS304 をストラウス溶液（JIS G0575）で粉末化した.この微 粉末を $100 \mathrm{~kg} / \mathrm{mm}^{2}$ で圧縮したのち， $1000^{\circ} \mathrm{C} て ゙ 30$ $\min$ 間炶結し再度加压した。 あとの加压は粉末焼結板に 存在する粒度情報をひずみを賦与することによつて消去 するためである。

Fig. 7 に示した架台の下に上述のカット・サンプルあ るいは標準試料をセットし高さを調整したあとに，各計 数管による X 線強度の計数值と (11) 式より計算された $D_{m}$ をプリントアウトした。1 回のプリントアウト終了 後, 架台車を約 $2 \mathrm{~mm}$ 水平移動し, 照射位置を变えて 测定した．この測定を 10 回繰り返したのち，算術平均 した $D_{m}$ を $\overline{D_{m}}$ とした.

测定にあたつては管電卮 $35 \mathrm{kV}$ ，管電流 $30 \mathrm{~mA}$ ，測

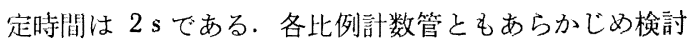
したプラトー領域の電压 $(1550 \sim 1700 \mathrm{~V})$ を Fig. 7 の 分压器(6で分压して印加した．本実駼を通じてX線計数 值は最高 $7000 \mathrm{cps}$ であり, 計数の数元落し率は $3 \%$ 以 内である。


のバラッキであり，サンプリング数を多くすることにならない. 
測定に供したサンプルの最近接した箘所から結晶粒径 測定用小片を採取した． $650^{\circ} \mathrm{C} ， 1 \mathrm{~h}$ 保持の鋭敏化を施 したのち，エメリーペーパーとバフで鏡面研摩仕上げし 10\% シュウ酸電解虏食 (JIS G057I) で組織を众出乙 た.このときの研摩上電解腐食による表面除去量はす心゙ てのサンプルで 15〜25 $\mu$ の範囲である. 結晶粒度の算 出はJIS G0552の切断法によつた。

\section{4. 実験結果および考察}

\section{1 測定位置に関する検討}

本手法は前述したように, 入射 X線, 被测定物, 計数 管の 3 者の幾何学的条件の制約を著しく受ける. あらか じめ故意にサンプル位置を基準点より变動させ，その量 がX線強度の計数值と $D_{m}$ に及ぼす影響を検討した。 て の結果を Fig. 8 に示す. この場合, X線の照射位置は平 面内で固定されており測定へッド部に対し垂直方向に高 さのみが変化している.測定に際し測定時間は $8 \mathrm{~s}$ とし $\mathrm{X}$ 線強度の計数値は 20 個の計数管による計数値の平均 值で，バックグラウンドの強度も含めている． $D_{m}$ は 20 個の計数管内での相対標準偏差であり，(11）式におけ る $n=20$ に相当する. 基準点よりずれるにしたがつて 回折X線の一部がアパーチャによつてカットされるため 計数值が低下し，バックグラウンドの寄与率が高くなつ $\tau D_{m}$ の低下をま权く。この計数值 $こ D_{m}$ の低下の現 象は必ずしも左右対称上なつていない，基準点に対しサ ンプル位置が偏倚する場合, 一側では $K_{\alpha_{2}}$ による回折 線がカットされはじめるので, 計数值はゆるやかな減少 上なるが，十側では $K_{\alpha_{1}}$ の回折線がカットされはじめ るので急激な低下となつて钼察される。一方， $D_{m}$ は $K_{\alpha_{1}}, K_{\alpha_{2}}$ の回折線とのものに精度情教をもつているた

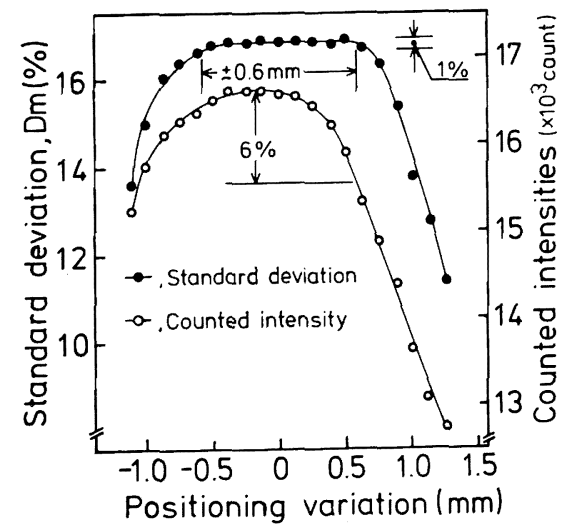

Fig. 8. Effect of positioning variation, which is deviated from standard position on standard deviation and counted intensities.
めに, サンプル位置の偏倚に対し愊広い胙谷領域があ る、いまかりに测定試料の高さ方向の位置のずれが测定 ごとに $\pm 0.6 \mathrm{~mm}$ の範围で変動するとすれば, 計数值 は 6\% 低下寸るが， $D_{m}$ は $1 \%$ の相対誤差を生じるに すぎない，この場合, 計数值の低下はアパーチャの愊を ひろげることによつて负がれるが，アパーチャの幅がひ ろくなると計数値に及ぼすバックグラウンドの寄与率が 大きくなり， $D_{m}$ とdとの感度が鈍くなることが考元ら れる. 試料の測定時の架台の移動にともなう高さ変動 は，基準点に対し $\pm 0.2 \mathrm{~mm}$ 以内におさまつていたの で高さ変動にともなう誤差は無視しうると考える.

\section{$4 \cdot 2$ 測定結果および考察}

117 個のサンプルについて求めた $\overline{D_{m}}$ と結晶粒径 $(d)$ との関倸を Fig. 9 に示す. 117 個のサンプルをすべて 1 つの目集団とみなし最小二乘法で, $\overline{D_{m}}$ とd との関係 を求めると $\overline{D_{m}}=0.66 d$ となる. 破線は, この $\overline{D_{m}}$ とd との関係式で求まる $d$ を中心にしてJIS で規定されてい る結晶粒度番号に掺算して， \pm 0.5 の範囲*を示すもの である. 図中の $a_{k} \sim d_{k}(k=1 \sim 3)$ は以降の検討におい て，各付号ごとに同じ原因で類似の挙動をとるものであ るため，本戝でその位置を明確にした． $\overline{D_{m}}$ とdとは良 い相関を示しているが， \pm 0.5 の範囲からはずれるデー 夕も一部見受けられる. Fig. 9 では製造工程が種々異な るにもかかわらず，117 個を1つの母集団として取り报 つている，たと穴ば冷延率の大きさで分類した I〜VII 別に咷的ると冷延率の低い I, N に存在し, 冷延率の高い II, VII $の \overline{D_{m}}$ は検量線の上侧 に存在する.すなわち, $\overline{D_{m}}$ とdとの間には I〜III別

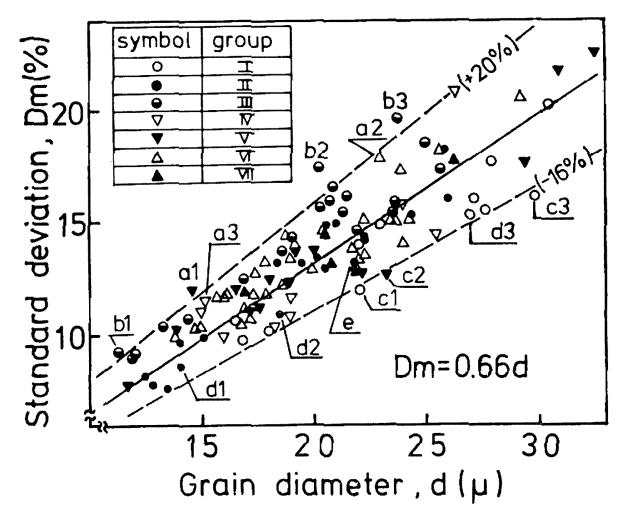

Fig. 9 Relation between standard deviation and grain diameter.

* 0.5 という值は特别な息味をもたないが，結晶䊉测定の JIS G055 の比娭法汃 JIS G0552 の切断法に対し, 测定值の約 $95 \%$ が \pm 0.5 以内におさまつているという䅅験から設定したものである。 
に異なつた剂係式が得られ，それぞれの䦔係式のもとで は全数 \pm 0.5 の箱围内打さまる。

これ穼で扱つてきた根底をなす理論はすべてデバイリ ングが円周方向に均一であること，すな⿰力ち結品方位は 全くランダムであるここを前提としている．しかし，测

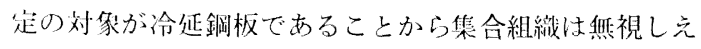
ないと考光られる7)。

試料面内で摇動させている試料にX 線を垂直入射さ せ, 試料法線に対し肩度 $34.25^{\circ}(=\pi / 2-\theta)$ をなす回折 面（311）の反射強度を $\beta$ (面内）回転して求めたもの 在 Fig. 10 亿示す. Fig. 10 の計数值の変化は垂直入射 によつて形成される (311) 面のデバイリングの 円周方 向にそつての強度変化を示している.この場合, 試料は 畮動されているために結晶粒径に関する情報は含まれて いない. 計数値の変化は集合組織に起因するものであ る. $b 2$ はデバイリングにそつての計数值の変化は大きい が, $e$ の計数値の変化は小さい.この計数值の変化の大き さは，冷延率の大きさに依存している。本結晶粒測定方 汒はデバイリングにそつての強度のバラツキを利用して いるた吕, 計数值には粒度情報と集合組織情報を含えで いることになり，Fig. 9 のように製造履歴の異なるもの 芯一つの母集団とみなすと, 集合組織に起因する強度の バラツキが情報の中に入り， $\overline{D_{m}}$ とdの関係を乱す。し たがつて集合組織に影跑を与える因子を抽出し，その因 子を類別して各々について $\overline{D_{m}}$ とdとの検量線を作成す れば，より信頼しうる検量線が作成しうる。しかし，そ れらの因子具体的にどのように頪別するかまた各因子 の相乘効果をどのように分割するかという点が不明であ る*. また検量線の数を增すことは煩雑さがともない本 研究の最終目的としているオン・ライン測定という立場 からは好ましくない。

この集合組織が及ぼす $\overline{D_{m}}$ への影響をキャンセルする

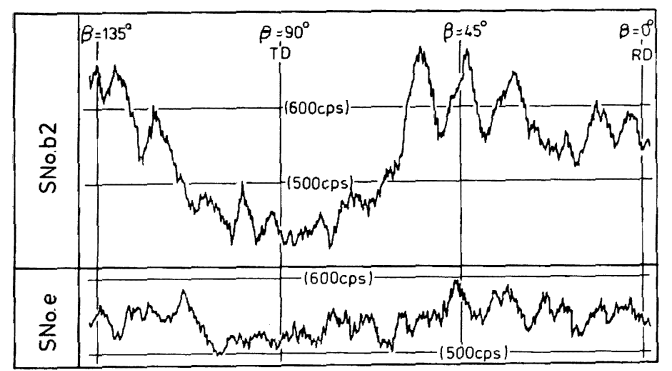

Fig. 10. Variation of the counted intensities of $b 2$ and $e$ along Debye ring.

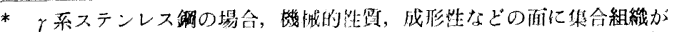


皆は少ない。
ためにアウト・プットした個々の計数值をもとに 95 個 のサンプルについて Fig. 11 のような処理を行なつた.

Fig. 9 に示した $\overline{D_{m}}$ は，Fig. 11 に拈子方列方向に求好 た $D_{i j}(j=1 \sim 10)$ を行方向に算術平均した $D_{J}$ に相当 する. この $D_{i j}(j=1 \sim 10)$ そのものに集合組織によ る影響も含まれているので， $D_{I}$ もとの影響を受ける.

Fig. 11 に求いてまず行方向 $D_{i j}(i=1 \sim 20)$ を求め列方 向に算術平均すると，Fig. 10 における $\beta$ 回転でのある 一点でのみ $D_{i j}(i=1 \sim 20)$ を求めていることから集合 組織の情報は混入されていないと考克られる.このよう にして求めた $D_{I}$ とdとの関係を Fig. 12 に示す. この 場合, 計数値のうちでバックグラウンドに相当する強度 はカットして計算したので, 最小二乘法で求めた $D_{m}$ と $d$ との関倸式の係数は Fig. 8 の場合よりも大きくなつ ている.この処理によつて, Fig. $9 て ゙ \pm 0.5$ よりはず れていた $b_{k}$ 系， $c_{k}$ 系が \pm 0.5 以内におさまつたが， 新たに $d_{k}$ 系が籁囲外にでた。ただ，乙の検量線は $a_{k}$ 系のデータが倸数を若干大きくしており， $a_{k}$ 系のデー タがないとすれば $d_{k}$ 系は \pm 0.5 以内に拉さまる.

この $a_{k}$ 系の $\overline{D_{m}}$ の異常性の原因および解決方法を次 に検討する. Photo. 2 は $a 2$ と $\mathrm{e} の$ 光学顕微鏡組織で ある. $a 2$ は母集団の大半の試料と異なり粒径の大きな 結晶粒が混在しているのが特徵的である. 切断法でほぼ

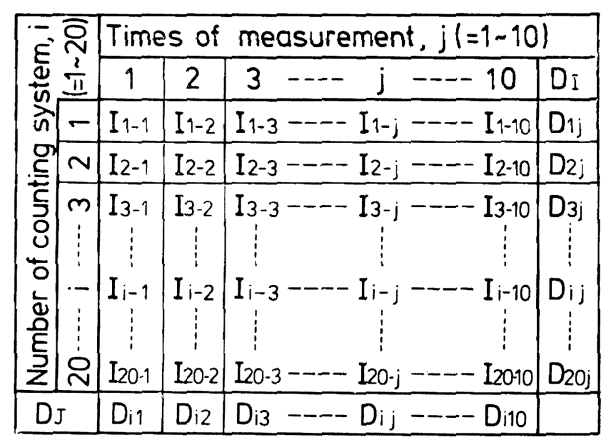

$\left(D_{J}\right)$

$$
\begin{aligned}
& D_{i j}=\sqrt{\frac{\sum_{i=1}^{20}\left(I_{i j}-\overline{I_{i j}}\right)^{2}}{(20-1)}} \times \frac{100}{\overline{I_{i j}}} \\
& \overline{I_{i j}}=\sum_{i=1}^{20} I_{i j} / 20, D_{J}=\sum_{j=1}^{10} D_{i j} / 10
\end{aligned}
$$

$\left(D_{1}\right)$

$$
\begin{aligned}
& D_{i j}=\sqrt{\frac{\sum_{j=1}^{10}\left(I_{i j}-\overline{I_{i j}}\right)^{2}}{(10-1)}} \times \frac{100}{\overline{I_{i j}}} \\
& \overline{I_{i j}}=\sum_{j=1}^{10} I_{i j} / 10, D_{I}=\sum_{i=1}^{20} D_{i j} / 20
\end{aligned}
$$

Fig. 11. Calculating method to remove the effect of texture. 


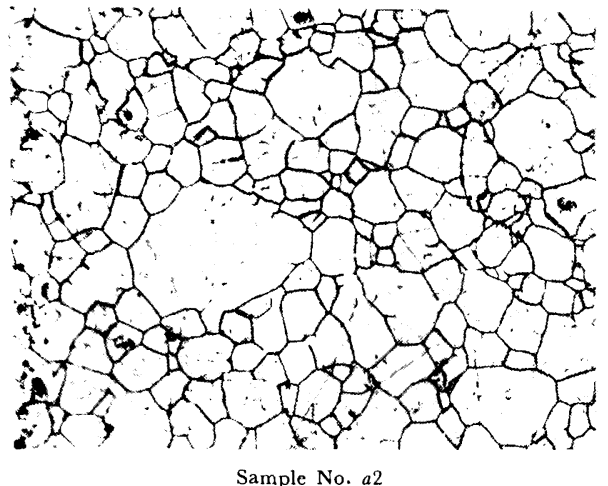

Sample No.

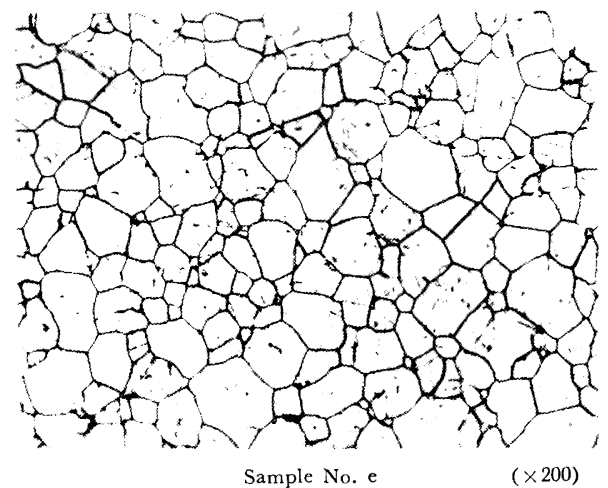

$(\times 200)$

Photo. 2. Microstructure of sample $a 2$ and e. The sample is sensitized at $650^{\circ} \mathrm{C} \times 1 \mathrm{~h}$.

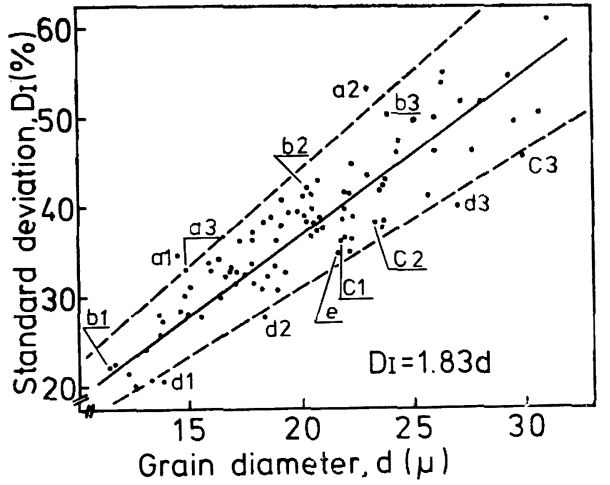

Fig. 12. Relation between standard deviation corrected texture, $D_{I}$ and grain diameter.

同じ粒径々判断された $a 2$ との結晶粒径々計数值の相 対比 $\left(I_{i} / \bar{I}\right)$ の分布を Fig. 13 に示す. 絬晶粒径の分在 は結晶粒の断面を円とみなし $4 \mu$ 間隔で類別し, 各サイ ズに属する個数を測定した，相対計数強度比は，集合組 織の影隌を取り除くため，各計数管ごとの 10 回の計数

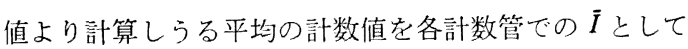
算出したものである・e の結晶粒径のヒストグラムは正 規分布に近いが， $a 2$ の場合は $18 \mu$ 以上の粒径の結晶粒 が約 $5 \%$ 混在している. 一方, e の相対計数強度比の ヒストグラムも正規分布に近いが， $a 2$ では相対計数強 度比が 2 以上を示吉場合が約 $6 \%$ 存在しており, 粗大結 晶粒の混在率とよく対応する. 以上の結果より $a_{k}$ 系の 場合は平均結晶粒径に対し粗大絬晶粒が存在し，たまた ま粗大結晶粒によつて回折されたところの計数值が高 く，この現象が $\overline{D_{m}}$ を大きくし粒度情報を乱していると 考えられる.

この現象は程度の差はあるが，各試料ともに其通して いることである. Fig. 11 で用いた行方向に求める方法
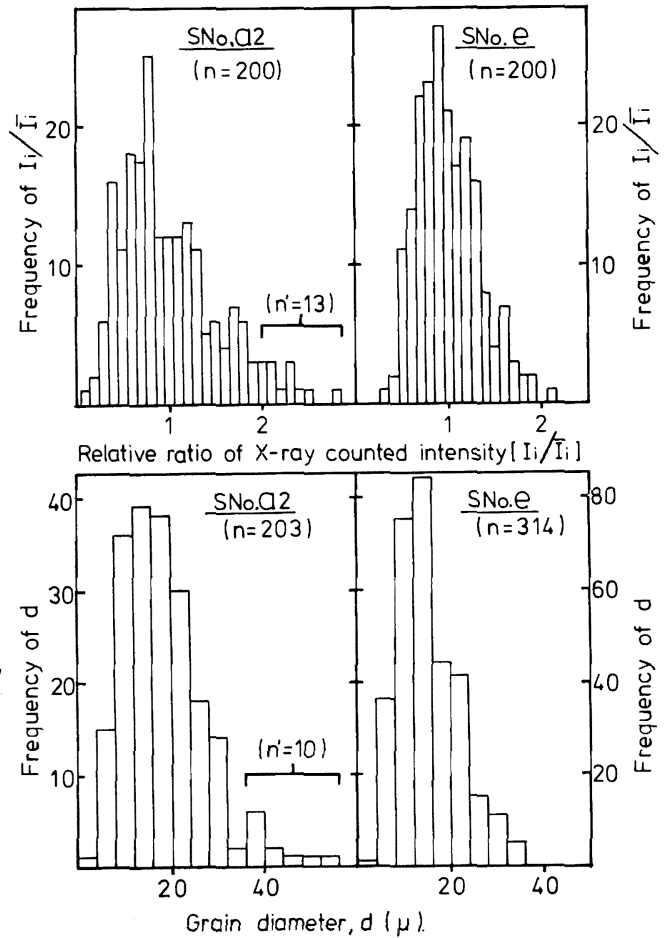

Fig. 13. Frequency of grain diameter and relative ratio of X-ray counted intensity.

で, $i$ 行目の 10 回の測定で求められる相対標準偏差を $D_{i}$ とする.

一方, 10 回の测定訃数值のうち最高值をカットした 9 回の测定值から求末る相対標準偏差を $D_{i}^{*}$ とする.こ の $D_{i}$ と $D_{i}^{*}$ との差 $\Delta D_{i}$ が $D_{i}$ に対しどれくらいの大 きさを占好か在恰定する。もし $J D_{i}$ が $\delta \cdot D_{i}$ よりも 大きい上きは，最も大きい計数值を示したものは粗大維 晶粒の情報が入つているとみなし，i行目の相対標準偏 


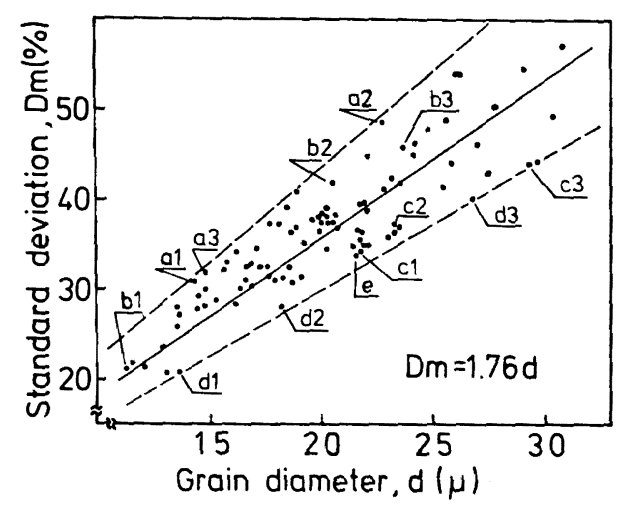

Fig. 14. Relation between standard deviation and grain diameter.

差は $D_{i}^{*}$ とする。もし $J D_{i}$ が $\delta \cdot D_{i}$ よりも小さいとき は，粗大結晶粒の情報はないとして， $D_{i}$ を $i$ 行目の 相对標準偏差とみなす。各々の“行”でこの検定を行な つたあとに列方向に算術平均すると，粗大結晶粒の混在 によつて生ずる相対標準㣂差への影楽はある程度除外さ れると同時に， $D_{i}$ が除外され $D_{i}^{*}$ が採用される回数の 多い材料は逆に粗大結晶粒が混在している材料であると 判定しうる.ただこの検定過程での係数 $\delta$ をいくらにす るか理論的に導き出せないそここで Fig. 12 に示した全 測定值が，結晶粒度番号で \pm 0.5 以内に执さまるべく するた如のの值を計算すると， $\delta=0.43$ という值が得 られた。この処理によつて得られた $D$ 上 $d$ と関係を Fig. 14 に示す.

(11) 式で表示しうる相対標準偏差に対し集合組織お よび粗大結晶粕の混入によるバラツキを補正すれば，精 度よく結晶䊀径を測定しうることがわかる。

\section{5. 結言}

と系ステンレス鋼の結晶粒度を非破壞的かつ迅速に测 定与る技術を開発与ることを目的とし，X線回折によつ て得られるデバイリングの斑点の数に注目して検討を行 なつた。

本研究で用いる原理が実際面で適用可能か否かの子满 実駼を行なつたのち，結晶粒度測定装犆の尃用機を試作 した。この試作機を用いて SUS304の商用忉について 結晶精度を測定した。

この研究を通じて得られた主な結果は次のと抢りであ
る。

（1）デバイリングの円周に沿つて分靔された各位置 で強度を計数し, 計数值の相刘標準偏差 $(D)$ を求好る と，このDは絬晶粒径 $(d)$ とよく対応する.

（2） $D$ とd との対応をよくするには， $D$ を求める 際のサンプリング数を大きくとらねばならない：この場 合，デバイリングの円周に沿つて分㓡された各位置での 強度を計数しうる数は装置上の制約をうけ，サンプリン グ数は 20 個となつた.サンプリング数を多くするため には，同一サンプルでX線照射位置を変光測定を繰り返 すことによつて目的を達成する。

（3）测定を繰り返すために移動与るときの計数管と 被測定物との距雖の変動は $D$ の精度に影響してくるが, $\pm 0.6 \mathrm{~mm}$ 以内であれ相対誤差は $1 \%$ 以内である.

（4） $D$ とd との刘応に直線性をもたらすためには, 一つのアパーチャに少くとも 3〜4 個の斑点が入るよう にアパーチャサイズを決定しなければならない。

（5）材料のもつ集合組織がDの值を大きくするが， 集合組織の集積度は製造履歴に影響されるので, 集合組 織の影䅧を補正与る必要がある。この補正は計算のみで 容易に行なえる.

（6）粗大粒が混在しているとDを大きくする．粗大 粒による影響も計算のみで補正ができる。なた同時に計 算上での情報をもとにして，材料における混粒状態の存 在茖検出, 指示しうる.

最後に本研究および開発に際し，いろいろ便宜を図つ て截きました日新製鋼(株)周南製鋼所所長山村隆将常務 取蟐役に心からお礼申し上げます。

\section{交献}

1 ) 例えば, $R$. STICKLER and $A$. Vinckier: Mem. Sci. Rev. Met., 60 (1963), p. 489

2 ) 例えば，ステンレス鋼便覧 (1973)，p. 87 [日刊 工業]

3) B.C. Cullity: 松村源太郎訳; X線回折要諭, (1970)，p. 272 [フグネ]

4) 林 建吉, 鳥居太始之: “微小焦点X 線回折なら びに細束X線回折技術”日本材料学会X線材料強 度部門委員会 (1970)

5 ) W. J. PRICE, 門口晃沢：放射線計算 (S. 41), p. 62 [コロナ]

6 ）志賀一法，北島邦男：日新技報，25(1971), p. 10

7) S. R. Goodman, H. Hu: Trans. AIME, 233 (1965), p. 103 